\title{
Unsheltered: Visions of Future Scarcity in the Past. Pablo Berger's Blancanieves and Jesús Carrasco's Intemperie
}

Jesse Barker

University of Aberdeen

jbarker@abdn.ac.uk

\begin{abstract}
This article connects the dehistoricized pasts in Pablo Berger's film Blancanieves (2014) and Jesús Carrasco's novel Intemperie (2013) to the present economic, cultural and ecological crises occurring within Spain and at a worldwide level. Both film and novel can be linked to contemporary anxieties: Blancanieves to an image-obsessed society of consumer abundance facing a present and future of increasing scarcity; Intemperie to the threat of environmental collapse. Their invoking of the past suggests that economic and ecological strife bring back the specter of past violence and misery, unleashing the negative affects that pervade an individualist society based on competition and inequality. The aesthetics of verbal silence in both texts encourage a raw affective engagement and are
\end{abstract}


analyzed here as a critical response to the individualist culture at the root of current crises, proposing alternative ethics of empathy and intersubjectivity. The social-political projects underlying these texts can thus be related to the $15 \mathrm{M}$ movement in Spain. They construct similar landscapes of anguish and hope, and they confront the same destructive ethos of fear, envy and domination that operate simultaneously on a societal level and within the self.

Keywords: Pablo Berger; Blancanieves; Jesús Carrasco; Intemperie

\section{Resumen}

Este artículo conecta los pasados deshistorizados de la película Blancanieves (2014) de Pablo Berger y la novela Intemperie (2013) de Jesús Carrasco con las actuales crisis económicas, culturales y ecológicas que ocurren en España y a nivel mundial. Tanto la película como la novela pueden vincularse a ansiedades contemporáneas: Blancanieves a la sociedad de hiperconsumo, obsesionada con la imagen, que enfrenta un presente y futuro de escasez creciente; Intemperie a la amenaza del colapso ecológico. La invocación del pasado en ambos textos sugiere que los conflictos económicos y ecológicos resucitan el espectro de la violencia y la miseria del pasado, desatando los afectos negativos que impregnan una sociedad individualista basada en la competencia y la desigualdad. Tanto en la película como en la novela, la estética del silencio verbal subraya la relación afectiva que los personajes mantienen con sus entornos. Dicha estética se analiza aquí como una respuesta crítica a la cultura individualista que es la causa de raíz de las crisis actuales, proponiendo éticas alternativas de empatía e intersubjetividad. De esta manera, los proyectos sociopolíticos que sustentan estos textos pueden relacionarse con el movimiento 15M en España. Como el $15 \mathrm{M}$, se enfrentan a las dinámicas de miedo, envidia y dominación que sustentan el individualismo.

Palabras clave: Pablo Berger; Blancanieves; Jesús Carrasco; Intemperie 
D oth Blancanieves and Intemperie recall narrative traditions based in a backwards rural Spain but universalize these settings. In Blancanieves, the use of the Snow White fairy tale and the visual referencing of European and Hollywood silent film, along with the over-the-top exploitation of Spanish stereotypes, mythologizes the 1920s Andalusian context. The film maintains the allegorical character of the fairy tale, but the true evil here is capitalist inequality and consumerism, the motors of the stepmother's destructive jealousy. Intemperie's setting is recognizably rural Spain, but the novel never specifies when or where the narration takes place. Its dystopian droughtstricken setting calls to mind the chronic droughts in Central and Southern Spain, but it can also be taken as an allusion to worldwide water shortages projected for the near future.

Although they dehistoricize Spain's past to some extent, they retain its legacy of scarcity and brutal exploitation. As is well known, Spain spent much of the twentieth century under abusive violent regimes, with an ingrained sense of lack: both material shortages and a lack of personal/social freedoms. The country was a late joiner to Western Europe's boom of consumer abundance and personal liberties and then was hit particularly hard by the 2008 economic crisis. So now we witness a strange moment in time, where abundance is still visible but scarcity also remains evident everywhere. New social movements and political parties seem to offer a profound and broad political engagement to citizens, but an ingrained establishment elite offers creepy specters of Francoera authoritarianism and patronage systems, including the recent irruption of Vox, the third largest party in parliament after the 2019 elections. To many the economic, political and social advances of the democratic transition appear to be a temporary illusion, now being dismantled by the global crisis. Likewise, in these texts the specter of past suffering and privations can be read as a haunting reminder of what will occur when our comfortable bubbles burst. The title Intemperie proves especially poignant in this sense, suggesting an 
array of meanings: exposed to the elements, out in the open, out of one's comfort zone, unsheltered. And the protagonists of these stories are both unsheltered-orphans on their own in unforgiving surroundings, dependent on the solidarity and help of strangers.

The word intemperie can also be taken as a mantra for Spain's present context. Unsheltered are those evicted from their homes, those with no possibility of stable work. Exposed to the elements are all of us under the threat of ecological disaster and economic collapse. Out of its comfort zone is a political, financial, and cultural establishment that has no script to respond to the economic situation, and much less to the new movements and political parties. Out in the open are those in the Indignados movement who built experimental cities and practiced face-to-face democracy in city squares. And finally out in the open we find the stories of precarious livelihoods and economic injustice that have long remained off the radar, as well as the public expression of outrage, anxieties and collective aspirations.

This context reflects the growing collective realization Slavoj Žižek discusses in his 2011 book Living in the End Times:

the global capitalist system is approaching an apocalyptic zero-point. Its 'four riders of the apocalypse' are comprised by the ecological crisis, the consequences of the biogenetic revolution, imbalances within the system itself (problems with intellectual property; forthcoming struggles over raw materials, food and water), and the explosive growth of social divisions and exclusions. $(x)$

Žižek suggests that our dominant social values and structures are leading us directly to oblivion. The very multiplicity of factors leading to this "zero-point" oblivion means we will not be able to divine its shape until we see it arrive, or until we awake one day to find that it has already been installed for quite some time. It is no revelation to point out that popular culture has produced a great number of apocalypse narratives of late and that these narratives, as fantastic 
as they may sometimes be, are a way of confronting fears and anxieties rooted in the four very real horsemen Žižek identifies. He focuses on these emotional cultural responses to a generalized sense of imminent disaster, categorizing them according to the five stages of grief that psychologist Elisabeth KüblerRoss outlined in cases of personal loss: denial, anger, bargaining, depression and acceptance (xi).

Acceptance of today's real situation, for Žižek, is tantamount to the recognition that the only viable political-social project is a complete disavowal of individualism. This transformation would pave the way for a "communist culture," which Žižek defines in his characteristically provocative style as "a shamelessly total immersion into the social body, a shared ritualistic social performance that would send all good liberals into shock with its 'totalitarian' intensity" (371). He does not pretend to know what form this new culture would take, only claiming to spy hints of it in scattered cultural manifestations in the present. John Gray argues that Žižek's iconoclasm is itself a product of the current cultural logic of late capitalism. He is a highly media-conscious public figure whose heterodox thinking made him unacceptable to the Communist establishment during the Cold War in his native Slovenia and has made him a celebrity enfant terrible within the global intellectual circles of the post-Cold War. Gray charges that he reproduces the contradictions of our "end times:"

With the prevailing capitalist order aware that it is in trouble but unable to conceive of practicable alternatives, Žižek's formless radicalism is ideally suited to a culture transfixed by the spectacle of its own fragility... In a stupendous feat of intellectual overproduction Žižek has created a fantasmatic critique of the present order, a critique that claims to repudiate practically everything that currently exists and in some sense actually does, but that at the same time reproduces the compulsive, purposeless dynamism that he perceives in the operations of capitalism. 
Žižek is symptomatic of a culture that foresees and perhaps at some levels relishes its own demise, struggling fitfully to break free of its own "purposeless dynamism," seeking to transform this manic solipsism into a total collective immersion.

The aesthetics of silence in Blancanieves and Intemperie can be related to the sort of raw affective engagement Žižek seeks. By silence I do not mean the absence of sound but rather of verbality. The floodgate of words is lifted in these texts, unleashing a raw affective engagement. Blancanieves uses the lack of spoken dialogue to overwhelm the audience with images and music. The gaps in dialogue direct our attention to the sensations and emotions we read on the characters' faces, in the soundtrack, in the rhythm of the images. They have an intoxicating effect, as does Intemperie's repeated references to the sun, the heat, the dryness of the air and land. The verbal interaction here is also minimal, and the protagonist's thoughts focus on the bare physical elements of survival: getting shade, water, and food; escaping the abusive bailiff (alguacil) that is pursuing him. Moreover, this raw affective engagement constructs alternative models of subjective relations, which break with the violence and domination that govern the worlds of both the film and novel. The focus on sensorial and physical interaction breaks down the subjectobject divide. In Blancanieves the stereotypical images and sounds of southern Spain transform from reified objects into active stimulants of intersubjectivity, porters of shared affective intensities. In Intemperie, the boy's inner landscape of neurons, cells, thirst and hunger enter into a fluid relation with the outer landscapes, people and animals he encounters when he runs away from his village. These dynamics provide glimpses of the type of "communist culture" Žižek envisions, the "total immersion in the social body" (371). Both Blancanieves and Intemperie feature characters that move from sheltered but highly exploitive domains to other ways of living in common with other people, animals and the Earth. They call on us, metaphorically, to leave our 
own bubbles, our Oedipal ego-homes, in order to face the pain, scarcity and potential solidarity on the outside.

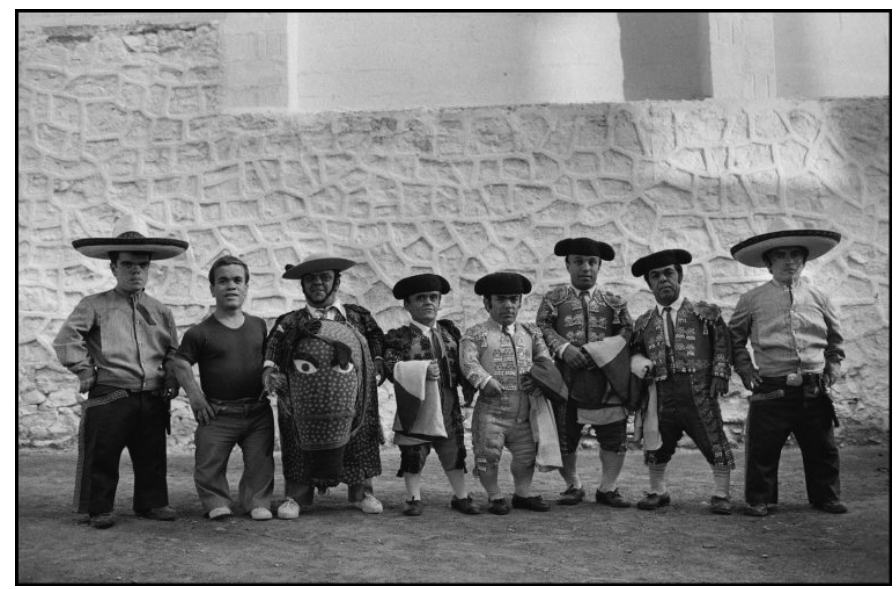

Figure 1a: photograph of bullfighter dwarves from García Rodero's España oculta

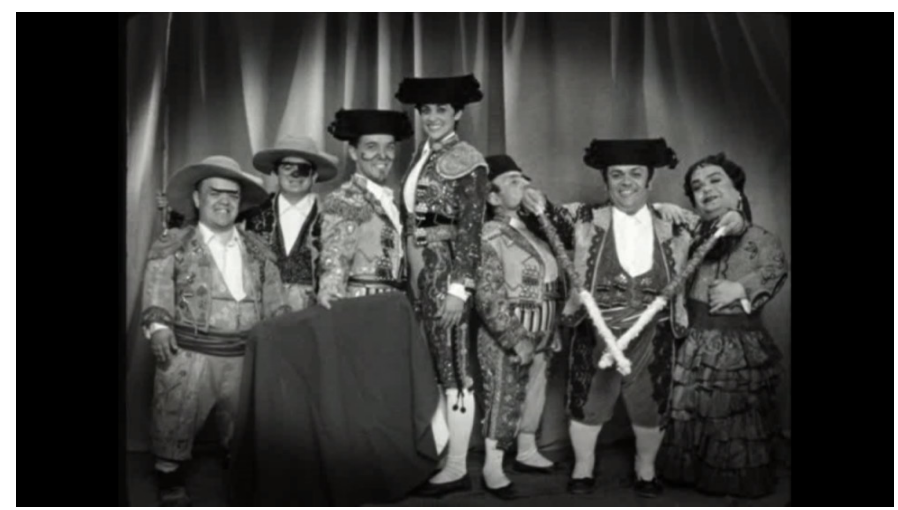

Figure 1b: photograph of Carmen and the bullfighting dwarves from Blancanieves 


\section{Blancanieves, a Capitalist Dystopia}

In Blancanieves, the protagonist Carmen is thrust into an environment of scarcity with the loss of her mother, her grandmother and finally her father. Like in classic versions of the Snow White tale she finds a new family in the dwarves. However, it is not a temporary refuge before being reinstated to her rightful place in the palace, but rather a reconnection to the outer world, to the affective engagement she had lost with the deaths of her family members.

One of the film's inspirations was photographer Cristina García Rodero's book España oculta (1989), which documents traditional festivities. Specifically, a portrait of bullfighting dwarves led Berger to reconfigure Snow White and the Seven Dwarves as a band of travelling bullfighters. Rodero's pictures, taken in the era of the transition to democracy, provide stark contrasts with the image of a modernized country portrayed on many fronts, most famously in the 1992 Barcelona Olympics. They bring up the complex relations between Spanish identity and traditions like these, as well as bullfighting and Flamenco more generally. These elements have been exoticized and essentialized by foreigners and by the Franco regime to sell Spain as a tourist destination, poeticized by Federico García Lorca and others, fetishized ironically by the likes of Pedro Almodóvar. To many in Spain, like Berger who is from Bilbao, they may seem distant from their own cultural background, connected to others like Gypsies, the rural poor or older generations. Yet at the same time they are in some way part of the collective cultural history. Therefore, when Berger and his team recreate a world of Flamenco and bullfighting within the aestheticized medium of an anachronistic silent film, they open up a long history of tensions between the use of these practices as collective cultural expression, on the one hand, and their use as instruments of objectification and domination on the other (Cox; Deveny).

These same tensions around images are played out in the story. In the first sequence a bullfight represents a stereotyped and patriarchal image 
of social cohesion, which is then torn apart, leaving Carmen to construct alternatives. Her father Antonio is a famous bullfighter and her mother, also named Carmen, is a famous Flamenco singer, pregnant in this scene with Carmen the daughter. The moment of collective anticipation before he attempts to kill the bull is drawn out through cuts to him, his pregnant wife, his manager, a newspaper photographer and the bull. As he moves in for the kill, though, Antonio is trampled by the bull and paralyzed from the waist down. The moment of tragedy moves across the screen in rapid-fire, choppy cuts that fuse the emotions we read on the faces of a larger group of people, those in the audience shown and the public implied by a newspaper photographer's camera. These images, in fact, pass before our eyes like a series of photographs, emphasizing the different individual persons and actions that are brought together in this moment of collective intensity. The image of a skull appears for a split second, almost subliminally, accentuating the specter of death that unites all these participants (08:36-09:42). The interconnecting element of mortality - the shared base element that defines our existence-is focused here on the patriarchal figure of Antonio. The collective energy of the social ritual, its totalitarian intensity in Žižek's words, gathers around this head of family and community hero.

Carmen is born into the world of shattered patriarchy resulting from the tragedy. Her mother goes into labor at this moment and dies in childbirth. A distraught Antonio rejects Carmen and she is raised by her grandmother, until she dies suddenly while dancing at Carmen's first communion. She then goes to live at her father's house where an emasculated wheelchair-bound Antonio resides under the power of the stepmother Encarna, who prohibits Carmen from visiting him on the top floor. The evident Oedipal undercurrents of this scenario pertain to our reading of the film insomuch as Carmen is born into a divided world of constant lack. However, she shows no sexual desire for her father or murderous desires towards her stepmother. The stepmother imposes 
the Oedipal regime of competition and domination but Carmen seeks selfrealization through affective attachment rather than differentiation.

The opposition between these two models of subjectivity is played out through the use of images and cultural practices. First of all, an ethic of intersubjective belonging is exemplified in portraits that Carmen and her parents wear around their necks as amulets. We see Antonio kiss a portrait of the mother before his bullfight (04:10). The mother opens the portrait of Antonio as she enters the labor room and drops it at the moment of her death (11:59). When Carmen is later strangled by the stepmother's lover the father's portrait also drops to the ground (52:12). These images of others, kept in the bosom and lost only with one's death or near death, are a part of the wearer in each case. The other forms a core part of the self.

Without physical interaction, though, these images express a loss of a part of the self. Throughout Carmen's early life, images of her parents in newspaper clippings and family photographs express distance from the ideal of affective belonging. Likewise, we often see her father gaze at her from a distance. At the communion he watches her from a car (21:30-22:05), and during her first days at his home he watches her cross below his window (29:48-56). In these scenes we do not see him but rather view her from his perspective, always distant and with the frames of the windowsills. Their mutual gazes are oneway and separated from each other. The different images-photographs and direct sightings-remain individual and cut off from the collective intensity presented at the beginning. The absence of Antonio's face when he sees Carmen expresses a sense of incompleteness within their forced separation.

On the other hand, the stepmother has a narcissistic relation to images, stimulated by consumerism and the media. In a twist on traditional versions of the story, the magic mirror that awakens her jealous rage is a society magazine, which puts the bullfighting Carmen on the front page and relegates a feature about her new home in Seville to a short secondary article (1:09:52-1:10:48). 
Significantly named Encarna-short for Encarnación, meaning incarnation in Spanish-she first appears usurping the role of the mother, as a drugged Antonio confuses their images. She is also constantly seen smiling for cameras in inappropriate situations, using her husband's fame to become a celebrity in her own right. In order to cement her new class standing, she has a grand portrait painted of herself as an aristocratic hunter. In the middle of the session she orders her lover to pose as a dog on her leash, underlining how her images, and cultural practices in general, are a means to domination and to establishing one's status and identity.
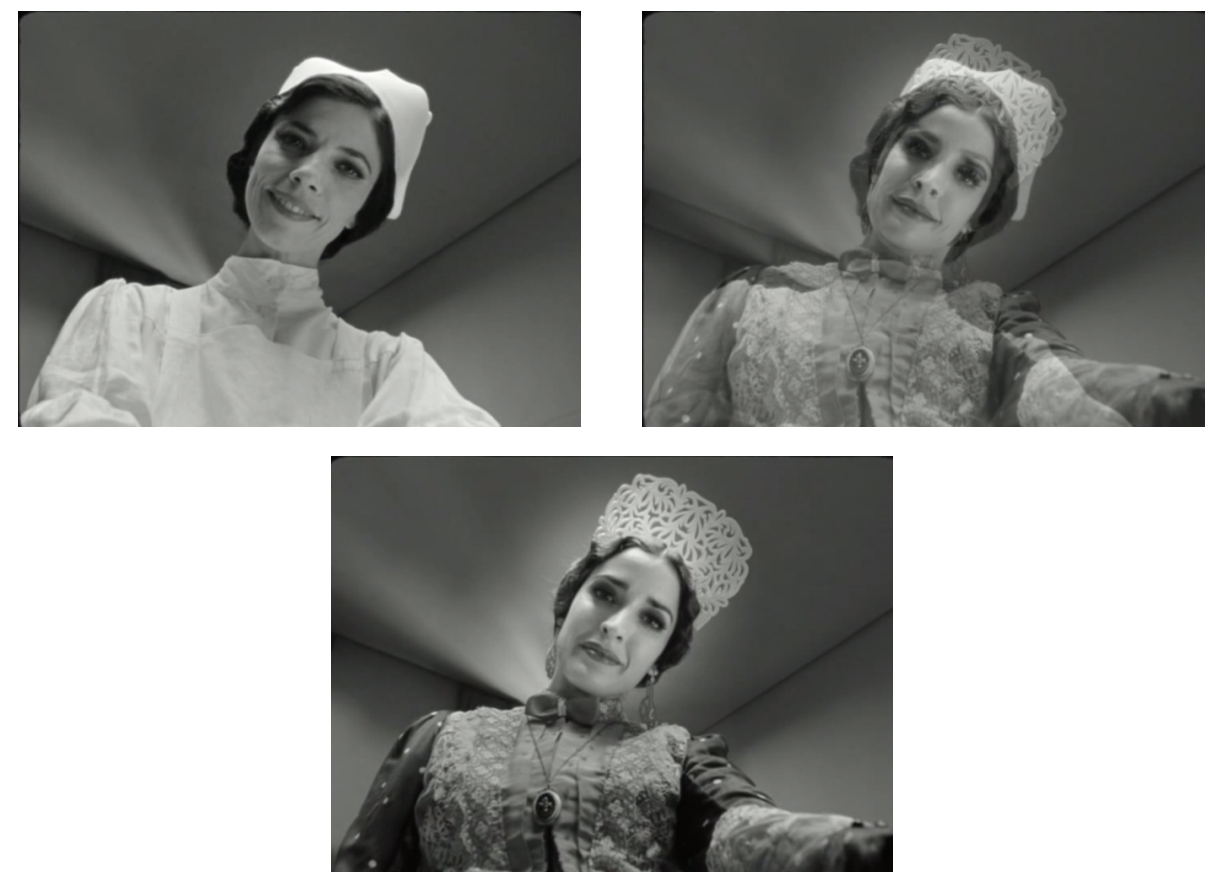

Figure 2: Point-of view shot where Antonio sees Encarna's face transform into that of his wife Carmen 
This is directly opposed to what is occurring down the hall, where Carmen now secretly meets with her father, performing Flamenco dancing and learning bullfighting moves. These cultural practices-based on movement, eye contact and the family-based transmission of skills-are portrayed as a means to affective interconnection. In an echo of Encarna's first appearance, Carmen is also seen incarnating her mother's image for her father (37:0004). However, in this case it is not usurpation but a sense of belonging to a family, a community, a world of physical and emotional relations. The film accentuates the moment when she violates the stepmother's prohibition and goes upstairs to finds Antonio sleeping, then reaching out to touch him physically (31:28-34:57). To get there she must cross the threshold of the staircase with an imposing painting of him on the landing. Rendered in the same rigid aristocratic style as the stepmother's portrait, he looks trapped in the dark background and his bullfighting uniform. As the patriarch has been emasculated, the community of two he and Carmen create is vulnerable. Eventually Encarna throws him down the stairs and he dies under his portrait (48:35-46). He has been destroyed by his own patriarchal image, which Encarna has usurped, after first usurping the role of the mother.

Upon his death Carmen is cast off into an underdeveloped rural society, highlighted in the film's second bullfight, when the dwarves perform a traditional "torero bomber" show in a small village. This burlesque version of a corrida, with small cows, acts as a dark parody of Antonio's bullfight. At first Carmen enjoys the antics of her new friends, but when the group's leader Jesusin is trampled the audience continues laughing. This is traditionally when the bombero would come out with a hose to distract the cow but the dwarves do nothing, complicit with the crowd's desire to see Jesusin suffer. The performers are not honored like Antonio but rather exploited for cheap entertainment. Shots of the crowd show a clear split between the poor members, with one extreme closeup revealing a smile of rotting teeth, and 
the local gentry, priests and men in opulent suits. The crowd's derisive laughter exteriorizes the divisiveness and violence of an unequal society. The pacing of the shots is fairly quick but nowhere near the photographic pacing of the first scene (56:03-59:16). They show us an assemblage of individuals united only in discord. They are not brought together by a collective intensity but by what Jacques Rancière has called "inequality's passion": "It is easier to compare oneself, to establish social exchange as that swap meet of glory and contempt where each person receives a superiority in exchange for the inferiority he confesses to" (80; emphasis in the original).

At this point, Carmen steps in to rescue Jesusin and proves to be an excellent bullfighter. Her skill soon brings fame and economic success to the group, which comes together to form a queer family unit, substituting the conventional family from the beginning. Unlike in traditional versions of the Snow White story, here the cross-dressing Josefa occupies the maternal role, cooking and cleaning for the rest. The young Carmen becomes the heroic bullfighter, and her adoring spouse, the enamored dwarf Rafita, a prince charming who, while handsome, is not a tall dark savior. This family's structure also subverts the centralized convergence around a single patriarchal figure. Carmen, Rafita, Josefa and the others reveal themselves as unconventional individuals with unexpected qualities. None of them would survive on their own but together they thrive. They echo the "communist culture" that Žižek perceives in recent pop narratives of superhero freaks like the $X$-Men and Heroes: a social interdependency that does not uniformize individuals but permits their particularities and even weaknesses to flower (376).

This family unit and Carmen's bullfighting career are inaugurated with an act of solidarity-saving Jesusín. But this act also places her directly within the ecology of "inequality's passion." A jealous Jesusín is yet another patriarch displaced, here by Carmen's superior skill. Despite presenting an alternative family unit, Carmen and the dwarves are also absorbed by the 
logic of a capitalist structure where she becomes the star and effective leader of the group. Additionally, she enters the socially constructed imagery of the bullfighter who asserts mastery over the angry irrational animal: an archetypal symbol of nature, raw life and death. This role within the community was broken with Antonio's downfall, and Carmen is perhaps destined to restore it but with the difference that she is a girl leading a tribe of eccentric dwarves. Thus she is placed in an ambiguous territory: between the patriarchal heroism of her father, the subaltern burlesque of the dwarves and something different that could install an alternative cultural logic. She has no desire for personal glory but rather pursues an ethic of affective interconnection and empathy. However, unable to read, she naively signs herself over for life to the exploitive promoter Carlos Montoya de Val and the fame he brings her incites Encarna's jealous rage.

All these interlocking elements culminate in the film's final bullfight, when Carmen returns to the arena of her origins, Seville's legendary Real Maestranza (1:14:32-1:46:38). As opposed to the idyllic first scene, here there are not only supporters present but also the evil stepmother, the exploitive manager and even within the family Jesusin, who switches the small cow she is supposed to fight with the bull set for the day's main attraction. Nobody knows Carmen's family history until Antonio's manager recognizes her. Just before she and the dwarves walk out to be presented to the public, he approaches her and says "hoy Antonio Villalta estaría orgulloso de su hija." The gravity of this phrase visibly affects Carmen and the words "Antonio Villalta" appear in large white letters across the screen. The extra-diegetic words combine with the emotion we read on her face, presenting her father's legacy as a source of affective intensity. When Carmen and the dwarves move/stand in the center of the ring, overexposed long shots show them alone under the blinding Seville sun: unsheltered. In a messy world of inequality and capitalist exploitation, Carmen finds herself engaged in a struggle to achieve a sense of belonging-to a 
family, to a community, to a collective history.

When she is face-to-face with the unexpectedly large bull, a handclapping Flamenco rhythm accompanies rapid photographic cuts between different images of her life, ending in an extreme closeup of her father's gaze. Similar rhythmic sequences occur earlier in the film when she dances with her grandmother after her communion and when she plays with her father and the stepmother is seen coming up the stairs with hunting dogs-both to her mother's singing on the record player. These sequences underscore the connection between rhythm, the passing of time and a basic sense of lived experience. Carmen's grandmother dies just as the record player finishes the song, and a threat of death hangs over the other two scenes, particularly here in the form of the bull. The sense of mortality and the photographic pacing, which in the first bullfight connected the participants in a collective affective intensity, now engage Carmen in a shared history. The remembered images of her father and the singing of the mother she never knew provide an affective archive of lived experience. Like the collectivity represented by the photographic pacing in the first scene, this coupling of music and images shows Carmen's life history not as a seamless whole but an assemblage of component parts contingently held together by an affective glue. The intensity of these musical sequences also stimulates the film audience to feel itself as participant in these assemblages, rather than distanced observers of reified stereotypes.

At this point Carmen is crying, overwhelmed by the weight of everything, her vulnerability and emotions exposed in front of the huge crowd. She turns and walks away from the bull, which begins to charge at her. But she again sees her father's face: an extreme closeup of his eyes is superimposed over hers and his words "Nunca dejes de mirar al toro," jolting her into action. The act of watching the bull is linked here to the mutual gaze of father and daughter. This intersubjective connection emphasizes the aspect of bullfighting that is not mastery over nature but integration with its movements and flows, 
observing the bull's body language, anticipating and responding in time to its rhythm-as Carmen does masterfully in this scene. She then turns to the crowd and looks surprised by their support and enthusiasm. Their clapping is synced with the flamenco soundtrack, a joining of Carmen's personal history to the collective energy of the shared moment in time. Her beaming smile appears not proud and grand but grateful and cathartic. The "totalitarian intensity" of this moment is not harnessed by a central figure but refracts rhizomatically through the bull, Carmen, the different audience members and the virtual presence of past histories. ${ }^{1}$

As Carmen celebrates her victory the veiled stepmother hands her the poisonous apple and thus defeats her rival. However, Encarna is eclipsed by a new villain, capitalist exploitation, represented by Carmen's manager. The terrified stepmother, trapped by the dwarves in the holding pen and killed by the bull, arouses the spectator's empathy. Earlier, the camera also shows her devastation after killing her lover in a jealous rage when Carmen surpasses her fame. She tosses him into a pool and here the water acts as the magic mirror, showing a very unflattering image of herself; trapped in her own narcissism, fomented by a consumerist image-obsessed society. Meanwhile, Carlos reaps the benefits of her evil, as he has the right to exploit Carmen for life and she is sustained in an eternal sleep. He encases this figure of purity and authenticity in a glass coffin, and builds a travelling fair around her, charging for the chance to kiss her and try to wake her. He uses the positive affects she inspires for financial gain. This final scene invokes a dark miserable society, where passion and desire are objects of commercial speculation, and pure affects are dormant or exist in small hidden spaces after the spotlights are shut off (1:34:20-1:35:30). 


\section{Intemperie, an Ecological Dystopia}

If Blancanieves ends with this capitalist dystopia, Intemperie's setting is characterized from the start as an ecological dystopia. The novel also features a child protagonist who runs away from home and faces the elements, fleeing his impoverished village in the middle of a drought-ridden landscape to escape the sexual abuse of the local bailiff. An old goatherd finds him nearly dead of thirst and exposure on the first day and teaches him to survive in the desert. Physical conditions are foregrounded throughout the novel, predominantly through the dryness of the landscape that penetrates the boy's body and mind. His inner landscape of thirst, hunger, and fear enters into a fluid relation with the outer landscapes, people, and animals he encounters when leaving the shelter of his home.

Blancanieves' aesthetic of verbal silence is reflected in the novel's focus on the physicality of these relations. The boy's thoughts are articulated as a series of impressions and sensations, rather than verbalized reflections. Thus the reader's attention is drawn to the bare material elements of survival, of existence within the world. The novel calls on us to leave our own sheltered bubbles in our imaginations, emphasizing the abject: sweat, blood, urine, feces, sex as forceful penetration, rot, rancid food, water filled with lime and maggots, human and animal carcasses. All those things that according to Julia Kristeva repel us because they break the carefully guarded border between the self and the outside, threatening a dissolution of autonomous subjectivity. But this exposure to the elements and to a dependence on others also constitutes the novel's glimmer of hope. The immersion in the intemperie provides a powerful image of affective belonging. Like Žižek's totalitarian intensity, the novel's acute physicality pushes the reader to peer beyond the boundaries of individualism. 
Intemperie has been adapted into a graphic novel (2016) and a film (2019), both of which translate the visual intensity of the novel's landscapes into their respective mediums. Javi Rey's stunning drawings in the former follow the story faithfully and effectively convey the novel's sense of physical fragility and abjection. Benito Zambrano's compelling film makes substantial changes to the story and characters. Unlike the novel, it is historically located in 1946 Spain, and the goatherd, played by the charismatic Luis Tosar, is younger, stronger and more talkative than the old man in the original. He retains the peace ethic that defines Carrasco's character, but it is not explicitly rooted in a religious attachment to the animals and landscape. Rather he has been shaped by his experiences in the Spanish colonial war in Morocco and the Civil War. When he is forced to act violently in the boy's defense, it plays out more like a conventional Western than the scene described below. These choices create an interesting contrast with the novel. In Zambrano's version war, not environmental collapse, is the main driving force behind the chain of masculine violence, which is broken in the relationship between the boy and the goatherd.

The novel opens with the boy buried in a hole carved out in the earth for his escape. Covered in darkness with no space to move, his body still forms a $Z$ shape. This underground immersion is described as a departure from his former self into the unknown and strange: "Perdido entre los cientos de olores que la tierra reserva a los lombrices y los muertos. Olores que no debería estar oliendo, pero que él había buscado. Olores que lo alejaban de la madre" (10). Lost in a foreign space reserved for the dead and the non-human, he endures, distanced from the origin of the self in the mother's womb. However, he later remembers this earthen pit as "El cuenco primigenio hecho con el barro de la verdadera madre" (204). His self-burial is thus staged as a death and rebirth: the enclosed Oedipal self perishes and makes way for a new being born of the "verdadera madre." This theme of rebirth echoes Carmen's immersion in an 
underdeveloped rural Spain in Blancanieves. Like the hunter in the traditional tale, the stepmother's lover is given the task of killing her rival, which he appears to carry out to completion, strangling the young girl until she collapses onto the forest ground. Found by the dwarves, her awakening in the bed of their rickety wagon can also be read as a sort of resurrection. Both these coming of age stories, then, feature chrysalis transformations that make the protagonists the brethren of otherness: worms, foreign smells, bullfighting dwarves. These conversions occur in the aftermath of the failure of the patriarchal nuclear family unit. Dethroned and unable to care for his daughter in the absence of the mother figure Carmen's father Antonio turns instead to a destructive substitute in the stepmother. In Intemperie the boy's father mutely accedes to the bailiff's violations, delivering his son to the abuser's home, and the mother is powerless to intervene, herself violently constrained by her husband.

The novel also parallels Blancanieves in questioning the image as a reliable form of knowledge of the world, accentuating other more enveloping senses, as suggested in the opening lines: "Desde su agujero de arcilla escuchó el eco de las voces que lo llamaban y, como si de grillos se tratara, intentó ubicar a cada hombre dentro de los límites del olivar. Berreos como jaras calcinadas... entrecerrando los ojos, aguzó el oído en busca de la voz que le había obligado a huir" (9). Like the prisoners in Plato's cave, he maps out the land and men through reflections, but here they are echoes of sounds rather than shadows of images. From a contemporary standpoint Plato's allegory is often read as showing the limitations of sight, associated with the subject's domination of the object world, which the knowing subject flattens into silhouette forms. In this opening passage, fear of his pursuer leads the boy to cut off this distancing sense and sharpen his ears to the sounds that configure a three-dimensional space, connected here with both the violent rage of male predators and the peaceful seductive song of crickets. Like the intensity of the music in Blancanieves, these sounds introduce the novel's major themes in 
non-verbalized formulations. They foreshadow the two structures of relations he will encounter on the desert plains: a law of violence and domination on the one hand, and a law of caring and coexistence on the other.

Initially he only knows the first law. The film establishes a clear parallel between him and the animals continually described as hunted, killed, and consumed by humans or by other animals. This dog-eat-dog world is exemplified by the following description of the region's greyhounds:

Alli sólo había galgos. Carnes escurridas sobre largos huesos. Animales místicos que corrían tras las liebres a toda velocidad y que no se detenían a olfatear porque habían sido arrojados a la Tierra con el único mandato de la persecución y el derribo. Flameaban líneas rojas en sus costados como recuerdos de las fustas de los amos. Las mismas que en el secarral sometían a niños, mujeres y perros. (10)

The greyhounds are a physical manifestation of scarcity and drained flesh, dried out like the land. The arid plain imposes a law of violence and deprivation that marks the body of those on the lower end of the social hierarchy with red lines and bare bones. Life there is a continual persecution, the same that the boy will evade throughout the novel and, like the greyhounds, will eventually be forced to carry out in order to survive. The punishing conditions are most poignantly felt in the barren land itself, with its crushing heat and lack of water, which nearly kills the boy on the first day of his escape. The logic of "inequality's passion" ingrained in the social structure thus appears to be a natural law coming from above, which throws these women, children, and dogs onto the harsh landscape to face their divinely mandated fates. This idea recalls the Spanish post-war form of naturalism known as tremendismo in classic novels like Camilo José Cela's La familia de Pascual Duarte, which naturalize the rampant violence and deprivation of the era as inherent qualities of the Spanish character. While the novel makes no specific reference to Spain, it is 
the recognizably central Iberian plains that impose the "nuevas reglas de la tierra seca" (77).

However, this phrase also implies that it was not always this way and does not necessarily have to be so. The specter of past Spanish violence and misery in the text ultimately suggests that economic and ecological strife unleashes the negative affects that pervade an individualistic society based on competition and inequality. As the boy wanders the empty riverbeds and the ruins of homes, wells, windmills, and villages that these former rivers supported, he instinctively and corporally feels its past, which contains other possibilities: “Caminando sobre la lámina de agua huida, sintió el impulso de tirar de las perneras para evitar que se le mojaran los bajos. Un deseo de agua fresca y limpia del que no era de todo consciente, pero del que sí lo eran sus células, pues era otro el modo en que la realidad les impresionaba" (63). His cells and desire are in contact with the past imprinted onto the land, which connects with other rivers buried in his memory. In another passage he remembers his village's layout around the riverbed, castle, and church-all a skeleton of its former self when water was abundant. The crops once moved in the wind like the sea but now the wind just breaks up the clay that remains. The olive trees are described as wounded but marching on, with this poetic conclusion: "No eran testigos del paso del tiempo, sino que era el tiempo quien les debía a ellos su naturaleza" (75). These passages suggest a material reality akin to what Deleuzian affect theory describes. Time is not an empty container but is rather thick with the stitching and unstitching of constant interrelation. Each object reveals a multiplicity of potentialities and past traces. The human subject is not an autonomous entity either but rather made up of a multiplicity of cells and senses that interact with the environment in layered complex patterns. Deleuze and Guattari (2013) argue that the self is a crossroads: "The self is only a threshold, a door, a becoming between two multiplicities" (291).

The intense physicality of the boy's struggle for survival also connects 
him affectively and materially to the animals on the plains. The law of violent submission discussed above has previously been imposed by the cold walls of the family home, silent witnesses to the father's beatings (14), and enforcers of the "ley ancestral" of childhood prostration (27). This law takes control of the bodies of women, children, and animals: the boy is delivered by the father to the bailiff to be violated within the similarly imposing walls of his home, lined with the trophy heads of hunted animals. Instituted within these domestic spaces, the law also penetrates within the enclosures of the boy's body, as is emphasized when he is lying in the dark pit at the beginning and the image of his servile father at the bailiff's side comes to his mind: "Una escena que, como ninguna otra, provocaba desordenes de todo tipo en su cuerpo" (12).

As mentioned above, though, the law is divinely ordained and thus permeates the landscape the boy finds beyond his prison home. The village's preacher delivers fire and brimstone sermons on God's designs, and the father tells the boy that his suffering must be punishment for something bad that he has done. Just as fear and angst drive the boy's body within, the divine will of suffering reverberates across the social body when he escapes, moving the men's bodies and voices over the surface of the landscape in search of him. If he was discovered, the boy imagines, they would form a whirlwind around him, cutting off the air and turning him into a match about to go up in flames (13). Such is the manner in which the affective intensity of a patriarchal society mingles with the physical conditions of the landscape, habituating itself on the bodies of its subjects within the expressive movement of a consecrated order of exploitation and abuse. Likewise, he later muses, the fear must already be running through the streets of his town, an invisible current that brings the village women to his home and around his mother: "arrugada como una patata, tendida lacia sobre la cama" (21). The bodies of the boy and the mother, like the bailiff's animal heads, serve as focal points for the aggressions and anxieties that move in currents around a hierarchal social order, which 
seems inextricably woven into the very land.

However, there are suggestions of an underlying effervescence in nature that hint at a different possible structure of being. For example, a barren fig tree calls up the boy's memory of eating the fruits in a "todavía inmaculado" past, before the drought and the bailiff's violations: "sin ser consciente, alguna parte de él se meció en un recuerdo agradable... Embriagado por la abundancia laberíntica y cavernosa de las pulpas calientes. Los colores de la maduración, la fina piel como una frontera delicadísima, o como un pretexto débil de la canícula para aguantar sólo hasta la llegada del tacto" (40). Like his cells that feel the absent river, this small part of him recalls the tact and smell of the fig's flesh. In contrast to the shriveled and exhausted body of his mother, the uterine imagery of the fruit suggests a feminine abundance, covered by a thin layer that gives way at the touch of his hand. It also offsets the aforementioned predominance of the abject in relation to the landscape and environmental conditions. Here the perforation of the "delicate frontier" between inside and outside, even under the dry sun of high summer, is sensuous and welcoming. While this memory may be idealized in the boy's unconscious mind, a description in the present of the goatherd's flock suggests a harsher but equally captivating lushness: "se alejaba despacio con su algarabía de balidos y cencerros templados en todos los tonos posibles... dejando tras de sí una estela de cagadas como la cola de un cometa" (57). The goats compose a strident but jubilant array of noises and even the trail of their normally abject dung is compared to the spectacular stream of light that a comet writes across the sky. This is significantly the moment when the goatherd tells him to come with them, signaling the boy's definitive welcome into the old man's protection and care.

From the goatherd he learns a different form of relation with the land and animals, which ultimately contains an alternative ethos to the violence and domination he knows. His first contact as he tentatively approaches the flock 
seeking food and water is with the dog, who is immediately friendly, giving the boy the sensation that his own earthen and urine smells bring him close to the dog world. He has left the bubble of human civilization, with its plumbing and roofs, and like these animals must live in direct contact with the land and all his body's functions. Later, when the goatherd has been beaten by the bailiff, he has to milk the goats and his inexpert hands come to terms with the physicality and will of these seemingly docile animals. In another passage, he shares a communicative moment of pained silence with the goatherd's donkey, after he accidentally hits the animal with a rock. He builds relationships with these animals beyond verbalized formulations and beyond their instrumental value as pets and livestock. Their raw physicality echoes his own intensity of sensation on the arid plain, and the mystery of their animal awareness reflects the multiplicity of his own consciousness.

The boy's major transformation occurs, however, through his relationship with the old man himself. A major point of tension centers on the goatherd's body, as the boy equates the masculine body with violent penetration. Like images in Blancanieves, physicality in the novel rides the line between domination and violence on the one hand and solidarity and affective attachment on the other. The narration offers sensuous descriptions of material elements such as the rancid cheese the goatherd gives the boy, the water jugs and sediment-filled water, the smell of the goats and the dog, and the afflicted, soiled bodies of the goatherd and the boy. These vivid descriptions of raw physicality can provoke queasiness, especially perhaps for urban readers with little experience of this sort of contact with nature. We are confronted with the intense materiality of life outside our sheltered and protected domains and can identify with the vague or clear threats that physical contact poses for the boy. In his sleep the boy nestles up against the goatherd and wakes up embarrassed and fearful. Later, when the goatherd is urinating, the sight of his penis also provokes the boy's anxiety, awakening suspicions of the old man's 
possible intention to deliver him to the bailiff.

The turning point takes place when the goatherd takes a harsh beating from the bailiff and his deputies without revealing the boy's hiding place. He then nurses the old man, whose body no longer represents a potential source of domination or intrusion. The boy is faced with the other's need, the pain on the goatherd's body that reflects his own, initiating a physical connection that is not sexual. This connection is then realized through an emergency apprenticeship where the boy follows the weakened man's instructions to carry out the actions necessary for their survival, as if his hands were connected to the goatherd's mind: "Las manos torpes del chico eran sus manos... fue resolviendo en silencio las tareas como un instrumento del pensamiento del otro" (122-23). These images contrast with the violence of an early passage in which the boy imagines traveling alone around the world, becoming so hardened that his fists turn into stones, his body no longer vulnerable to the bailiff's violations. Instead, the goatherd has endowed him with tender hands that tend to wounds and care for others. In this sense the boy's vocational apprenticeship with the old man becomes an ethical education. The goatherd introduces an ethic of care and protection, breaking with the law of violence that rules the desert plains.

The climactic scene where the bailiff finally finds the boy reinforces the novel's themes of vision and domination. I have already discussed how the boy's initial burial downplays sight in favor of more immersive senses and have also commented the unsettling reverberations the boy's visual memory of his father's face next to the bailiff has in his body. Images in the desert landscape are likewise shown to be disorienting and incomplete, often taking on a sinister air. Only the night sky appears to offer a clear vision, with the North Star constantly marking the boy's escape route to an imagined mountainous utopia. Before raping him, the bailiff in this scene repeatedly exhorts the boy to look up at him as an ultimate sign of submission to the man's power, but 
the child mutely refuses. The candle flame that lights the room where they are then runs out, leaving them in darkness just as the bailiff is beginning his violation, providing a fortuitous pause before the goatherd breaks in and shoots the rapist. The boy is thus spared the terrifying vision of the bailiff first by the darkness and secondly by the goatherd's bullet.

The boy hears the bailiff's head hitting the ground and, with his eyes closed, imagines the gruesome spectacle as the cutting of an overripe zucchini's skin, an image that stands in direct contrast with the earlier description of the fig's tender flesh: "La piel gruesa que sólo cede ante el machete y la pólvora, y la densidad de una pulpa apretada y harinosa que lo llena todo y que, en su repentino colapso, se derrama" (196). As opposed to the fruit's tender flesh giving way to the light touch of the hand and revealing its warm abundant pulp, here we see a thick skin that only parts through violent action and a dry pulp that spills out inertly when its tight enclosure is penetrated. The parallel descriptions of the opening up of a fig fruit and a human head set up a surprising equivalence between them as material objects. But it also sets up a poetic contrast between nature's plenitude and interconnectivity, represented by the fruit, and human society's tendency towards violent separation and atomization, epitomized in this tyrannical law enforcement officer.

The narration, however, underlines the fact that the boy does not actually see the bailiff's head or process what is occurring, as his eyes are tightly closed in a state of shock. In a repetition of the abuser's earlier exhortation, the goatherd breaks through his stupor, ordering the boy to look at him: "La intensidad de sus pupilas atrayendo su atención para impedirle la visión de la cabeza reventada del alguacil" (197). The old man wants to avoid him seeing the ultimately terrifying and sinister vision of the dead bailiff, which might haunt the boy's future. Instead he turns him to face a different intensity, that of his embracing eyes, the protecting and caring gaze. This gaze composes a vision constant and clear like the stars, soothing like the imagined mountainous 
land, bountiful like the ripe fruit. It breaks the boy away from the vicious cycles installed by enthralling visions of destruction, cruelty and avarice.

The silent intensity of the goatherd's eyes reflects the general intensity of the intemperie in the novel: a great outside that impinges on the boy's vulnerable body. The intemperie emphasizes the animal need for food and water, a stringent reminder of our dependence on interaction with the outside, but the outside is also continually associated with the abject. For the boy, in particular, the bailiff's violations of his body have turned all physical contact into a terrible violence that impregnates his vision of everything. He has always experienced the other as an intrusion, an abusive domination, but gradually learns to open up his personal space to the old man, entering a communal dynamic that reconfigures his worldview. It shows on a small scale the breaking with individualism that Žižek advocates, an opening up to the otherness of the world, which is inherently a part of the self. Like in Blancanieves, the moment of opening up is configured as a mutual and penetrating gaze: breaking through the mask of individualism, which congeals affective relation, naturalizing domination and domestication.

\section{Spaces of Invitation}

Both Blancanieves and Intemperie bring up a dark Spanish past in order to invoke the destructive impulses that emerge in times of economic and ecological upheaval, resulting from individualist responses to these problems. Rejecting inequality's passion, they seek alternative cultural modes of solidarity and intersubjectivity. These are the same issues faced by the $15 \mathrm{M}$ movement that convulsed Spain in 2011, occupying central urban squares and constructing experimental communal cities. According to Amador Fernández Savater, they rose up against the imposed consensus of the "Cultura de Transición:" the technocratic control of society's functioning through elite expert classes of politicians, economists and intellectuals that set the agenda and the limits 
of what is possible. The Culture of the Transition implanted the myth that without these central authority figures society would break down into chaos. This consensus was highly debilitated by the economic crisis, however, and received its first great challenge from the Indignados (667-69). The collective outrage voiced in city squares can be compared to Žižek's notion of totalitarian intensity. Like Carmen's bullfight, it is rhizomatic rather than structured around a centralized figure. This lack of central authority led to self-organization: "a los pocos días no estábamos allí para gritar nuestra indignación contra nadie, sino por la belleza y la potencia de estar juntos, ensayando modos de participación común en las cosas comunes" (676-77). Inside narratives of the 15M experience like this one emphasize a sense of affective belonging. However, immersed in a competitive and unequal society, the participants recognized that it was a necessarily temporary experiment and dismantled the tent cities in order to try to spread the alternative culture germinated there to all sectors of society. Like in Blancanieves, they engage in a complex struggle against the dynamics of envy and capitalist exploitation.

As Fernández Savater recognizes, though, it is also a struggle with one's own distrustful and individualistic tendencies. The occupied squares became "espacios de invitación” but, as he points out, "Invitar no es una operación sencilla: hay que confiar en el desconocido, saber acoger, tener algo que ofrecer, evitar los cierres identitarios, estar dispuesto a dejarse alterar por lo que el otro tiene que traer, permitir al otro reapropiarse del espacio y reconfigurarlo a su gusto, etc." (677-78). Intemperie shows this process on a personal scale. The boy who has always experienced the other as an intrusion, a violent domination, gradually learns to open up his personal space to the old man, entering a communal dynamic that reconfigures his worldview, and converts the boy himself into a goatherd, living in common with the animals and the land. 
Like the $15 \mathrm{M}$ movement, these texts confront the complex social-political project of breaking with individualism, opening up to the otherness of the world, which is inherently a part of the self. It might be tempting to read these texts as rooted solely in past contexts or, in the case of the film, as a purely aesthetic exercise playing on stereotypical images and emotions. However, employing affect theory, we can frame their dehistoricized pasts as allusions to contemporary problems. Following Žižek's thesis discussed earlier, we already know things are horribly wrong. Rather than directly invoking current issues, these texts seek an acceptance of what we already know: that individualism dooms us to a future of suffering and regret. Acceptance approximates something like knowledge but it spreads beyond our verbalized thought to our senses, our nerves, to the amygdalic processing of affect. This will likely only occur when we are truly unsheltered and out in the open, but Blancanieves and Intemperie call on the resources of literature and film to produce that sensation of leaving our comfortable bubbles and being exposed. They then work to convert that sensation of vulnerability into a sensation of release and unraveling: the ego-home of the self-giving way to a total affective immersion in the surrounding environment. This is the glimmer of hope these texts find in their otherwise dystopian future pasts.

\section{Notes}

This article is a modified version of a chapter in my book Affect and Belonging in Contemporary Spanish Fiction and Film: Iberian Crossroads (Palgrave Macmillan, 2017).

1 See Deleuze and Guattari for a discussion of rhizomes and affective fields, as opposed to the classic image of the tree and hereditary identity (3-29). 


\section{Works Cited}

Blancanieves. Directed by Pablo Berger, Arcadia, 2012.

Carrasco, Jesús. Intemperie. Seix Barral, 2013.

Cela, Camilo José. La familia de Pascual Duarte. Planeta, 1977.

Cox, Anna K. "Interrogating the Real: Race and Remediation in Pablo Berger's Blancanieves." Bulletin of Hispanic Studies, vol. 94, no. 3, 2017, pp. 315-36.

Deleuze, Gilles, and Félix Guattari. A Thousand Plateaus: Capitalism and Schizophrenia. Translated by Brian Massumi, Bloomsbury, 2013.

Deveny, Thomas. "A Film Version of Snow White with a Spanish Twist." Marvels \&Tales, vol. 30, no. 2, 2016, digitalcommons.wayne.edu/marvels/vol30/iss2/10.

Fernández Savater, Amador. "El nacimiento de un nuevo poder social." Hispanic Review, vol. 80, no.4, 2012, pp. 667-81.

García Rodero, Cristina. España oculta. Lunwerg, 1989.

Gray, John. "The Violent Visions of Slavoj Žižek." Review of Less than Nothing: Hegel and the Shadow of Dialectical Materialism and Living in the End Times. The New York Review of Books. July 12, 2012, www.nybooks.com/articles/2012/07/12/ violentvisions-slavoj-zizek/.

Kristeva, Julia. The Powers of Horror: An Essay on Abjection. Translated by Leon Samuel Roudiez, Columbia UP, 1982.

Intemperie. Directed by Benito Zambrano, Morena Films, 2019.

Rancière, Jacques. The Ignorant Schoolmaster. Translated by Kristen Ross, Stanford UP, 1991.

Rey, Javi, and Jesús Carrasco. Intemperie. Planeta Cómic, 2016.

Spinoza, Benedictus de. A Spinoza Reader: The Ethics and Other Works. Edited and translated by Edwin M. Curley, Princeton UP, 1994.

Žižek, Slavoj. Living in the End Times. Verso, 2011. 